\title{
Shifting to Renewable Energy to Mitigate Carbon Emissions: Initiatives by the States of Gulf Cooperation Council
}

\author{
Hilal Al Shidi, Hameed Sulaiman*, Patrick Amoatey \\ Department of Biology, Sultan Qaboos University, Muscat, Sultanate of Oman \\ Email: "hameed@squ.edu.om
}

How to cite this paper: Al Shidi, H., Sulaiman, H. and Amoatey, P. (2016) Shifting to Renewable Energy to Mitigate Carbon Emissions: Initiatives by the States of Gulf Cooperation Council. Low Carbon Economy, 7, 123-136.

http://dx.doi.org/10.4236/lce.2016.73012

Received: June 15, 2016

Accepted: August 7, 2016

Published: August 10, 2016

Copyright $\odot 2016$ by authors and Scientific Research Publishing Inc. This work is licensed under the Creative Commons Attribution International License (CC BY 4.0).

http://creativecommons.org/licenses/by/4.0/ (c) (†)

Open Access

\begin{abstract}
The Gulf Cooperation Council (GCC) countries approximately have $40 \%$ of world's proven oil reserves and $21.7 \%$ of world's known gas reserves. Low energy costs compiled with low taxation make it lucrative to foreign energy-intensive companies to operate in the region. Energy consumption in GCC has increased by $74 \%$ in the period between 2000 and 2010 and it is projected to increase by approximately $10 \%$ to 15\% between 2010 and 2020. Embracing the general commitment by GCC states to reduce greenhouse gas emission (GHG) of United Nation Framework Convention on Climate Change (UNFCCC) has started the process of environmental awakening in the GCC countries due to its high vulnerability to the effects of climate change. This paper reviews the trends in shift to renewable energy with reference to GCC and also the co-benefits of investing in renewable energy. Solar plant and Building-Integrated Photo-Voltaic (BIPV) systems are the most invested projects. However in the long run, policies and strategies are needed to ensure the successful and larger implementation of mitigation objectives.
\end{abstract}

\section{Keywords}

Renewable Energy, Climate Change, GCC States

\section{Introduction}

With regards to the climate change policy of the Gulf Cooperation Council (GCC), a trade bloc consisting of six Arab States of the Arabian Gulf (Bahrain, Kuwait, Oman, Qatar, Saudi Arabia and the United Arab Emirates) was created in 1981. The GCC member states are the major oil and natural gas producing countries [1]. GCC states have approximately $40 \%$ of world's known oil reserves and $21.7 \%$ of world's known gas 
reserves [2].

Their economies are heavily depended on the crude oil and natural gas. Exploitation, extraction, processing, transportation and use of theses fossil fuels are associated with several environmental issues including climate change. Carbon dioxide $\left(\mathrm{CO}_{2}\right)$ is the most abundant anthropogenic greenhouse gas responsible for global warming, released in enormous quantity at different stages of crude oil production. Figure 1 and Figure 2 show natural gas and oil consumption levels of the GCC countries in 2013 based on International Energy Agency (IEA) report, among which Saudi Arabia and United Arab Emirates are the leading consumers [3]. Indeed, these member states are still leading the international ranking of climate-polluters. According to 2009 global ranking of $\mathrm{CO}_{2}$ emissions (metric tons per capita), Qatar ranked first, Kuwait third, the United Arab Emirates fifth, Bahrain seventh, Saudi Arabia eleventh, and Oman thirteenth, among a total of 214 countries [4]. Power plants are the major source of $\mathrm{CO}_{2}$ emissions.

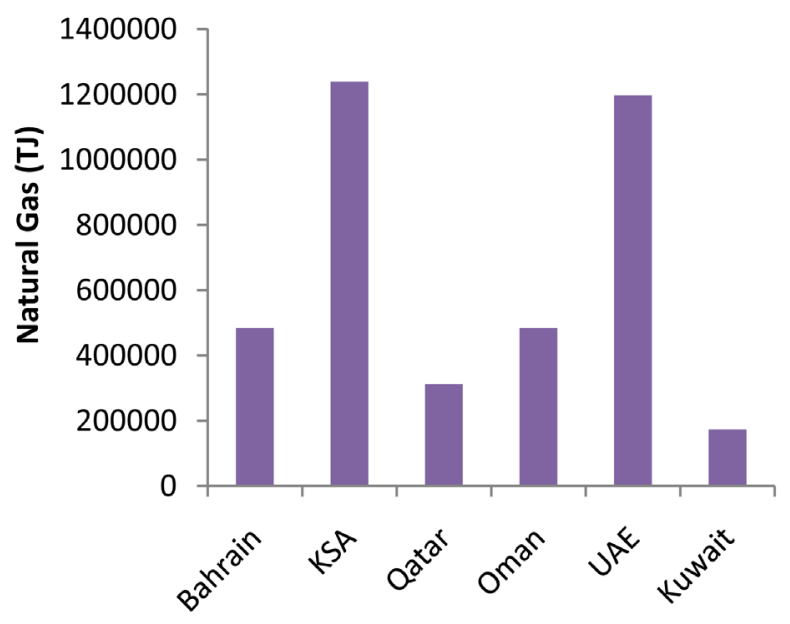

Figure 1. Natural consumption (TJ), 2013 [3].

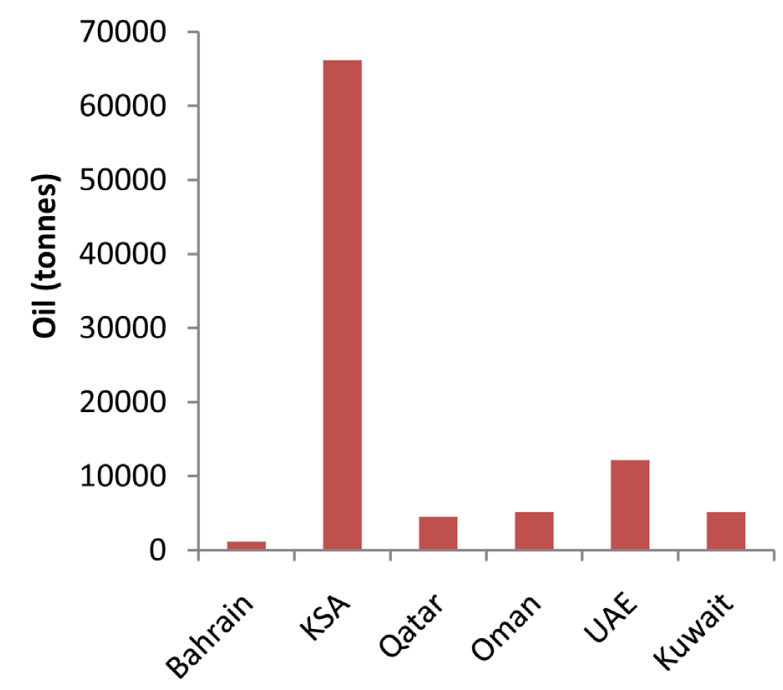

Figure 2. Oil consumption (10 tonnes), 2013 [3]. 
This is attributed to three main factors; first of all, the phenomenon of growth of urban population and increase in their purchasing power due to influx of migrant workers to GCC countries has led to reinforcement of national population growth. Second, the process of economic diversification and industrialization and thirdly, the relatively low price of energy to industry [5].

Electricity consumption is increasing at faster rate in GCC countries: $12.4 \%$ from 2005 to 2009 (3.15\% per year). This rate is much higher than the world average of $2.2 \%$ for the same period. Average per capita electricity consumption in GCC region was 10,976 kilowatt-hour $(\mathrm{kWh})$ in 2009 , which was 3.9 times more than the world average of $2806 \mathrm{kWh}$ [6]. Kyoto protocol has ignited political and public concern regarding the impact of energy utilization on climate and environmental degradation resulting in a move at global level towards a low-energy consumption culture [7]. The United Nations report on global warming "Climate Change 2014: Impacts, Adaptation and vulnerability" calls for a major shift from the usage of fossil fuel to renewable resources [8]. Development of renewable energy technologies is now globally accepted as a crucial component of providing an integrated solution to reduce greenhouse gas emissions, fostering innovation and providing access to secure, clean and affordable energy [9].

Though, all GCC countries have ratified the International Renewable Energy Statute of increasing the share of renewables in their energy grids and yet, there is considerable variation in the adoption of renewable energy technologies; while others are actively engaged in the development of renewable energy, other countries appear to be lagging behind [4].

In order to contribute to domestic energy security as well as long-term economic and environmental sustainability, the GCC countries must act decisively to take the merits from many benefits of investing in renewable energy projects for the local market; the greater usage of renewable energy will lead to lesser oil and gas consumption which can remain for export, increasing revenue for the GCC countries [9]. This paper reviews the trends in shift to renewable energy with reference to GCC countries with co-benefits of investing in renewable energy but also suggests policies and strategies needed to ensure the successful and broader implementation of mitigation objectives.

\section{Drivers of Electricity Consumption}

A study postulate [10] that there is a positive linkage between trade, income and energy consumption in the Middle East, so any intervention in energy conservation is likely to have profound impact on economic growth. Internal migration has led to increasing population density in urban areas and this has resulted in high proportion of the population enjoying the significant improved living standards resulting in an increased size of average dwelling, universal reliance on air conditioning and high usage of household appliance [2]. Another determinant of energy consumption in GCC countries is price, the cost of energy to consumers and industries are low [11]. It is reported that high energy consumption in GCC states is due to growth of development and infrastructure and investment in energy [12]. Table 1 shows that electricity consumption in GCC has 
Table 1. Electricity consumption in GCC countries for 2011 and 2013 compared with USA, EU, Africa, China and World [3].

\begin{tabular}{ccccc}
\hline Country/Region & $\begin{array}{c}\text { Consumption } \\
\text { TWh (2011) }\end{array}$ & $\begin{array}{c}\text { Consumption } \\
\text { TWh }(2013)\end{array}$ & $\begin{array}{c}\text { Population } \\
\left(10^{6}\right)(2011)\end{array}$ & $\begin{array}{c}\text { (MWh/capita), } \\
2011\end{array}$ \\
\hline Bahrain & 22.9 & 24.58 & 1.29 & 17.71 \\
KSA & 226.57 & 264.0 & 27.76 & 8.16 \\
Qatar & 28.82 & 32.51 & 1.91 & 15.08 \\
Oman & 19.03 & 23.37 & 3.03 & 6.29 \\
UAE & 92.04 & 98.58 & 8.93 & 10.31 \\
Kuwait & 50.38 & 53.58 & 3.13 & 16.12 \\
\hline GCC Total & 439.74 & 496.62 & 46.05 & 73.67 \\
\hline USA & 4127.31 & 4109.84 & 312.03 & 13.23 \\
EU & 3099.55 & 3066.53 & 506.30 & 6.12 \\
Africa & 622.00 & 649.15 & 1056.10 & 0.59 \\
China & 4432 & 5121.93 & 1340.00 & 3.31 \\
World & $20,444.69$ & $21,537.90$ & 6950.94 & 2.94 \\
\hline
\end{tabular}

increased at a faster rate. USA and EU has been able to decease their total consumption from 2011 to 2013, this is different in GCC where consumption has rather increased from 2011 to 2013. This attests to the fact that USA and EU are adopting renewable energy policies in reducing electricity consumption and overall GHG emission reductions.

\section{3. $\mathrm{CO}_{2}$ Emissions in GCC}

GCC countries are ranked as one of the top per capita contributors to global pollution. Only $0.6 \%$ of the world's populations resides in the GCC countries, yet the region contributes $2.4 \%$ of greenhouse gas (GHG) emissions [13] as shown in Table 2. Energy intensities, $\mathrm{CO}_{2}$ per GDP and $\mathrm{CO}_{2}$ emissions per capita in GCC countries are higher than European Union and Organization for Economic Cooperation and Development (OECD) [14]. According to International Energy Agency [15] all GCC countries fall in the top 25 countries responsible for the highest per capita $\mathrm{CO}_{2}$ emissions.

According to a report [16] on total $\mathrm{CO}_{2}$ emissions in kilo tons (kt) in 2009, GCC accounted for $2 \%$ compared to $9 \%$ of European Union and 13\% of United States as shown in Figure 3.

\section{Climate Change Vulnerability of GCC}

GCC countries are ranked as high category for vulnerability to the effects of climate change. The social, economic and ecological impact of change in climate is expected to 


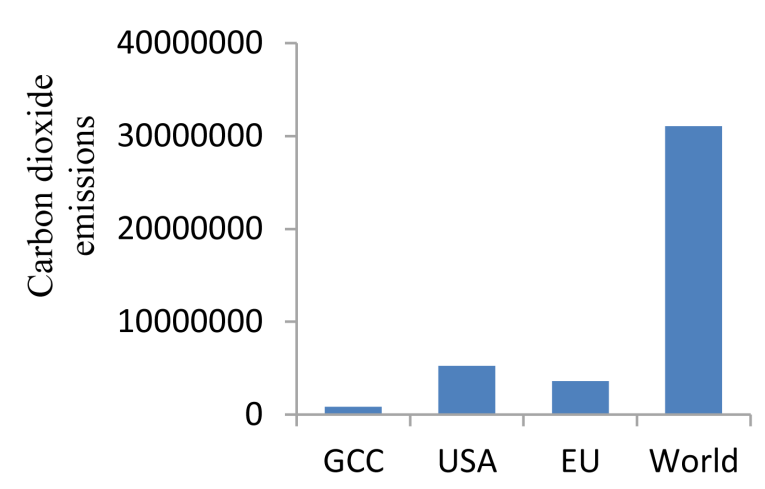

Figure 3. $\mathrm{CO}_{2}$ emissions (kt) in 2009 [16].

Table 2. Per capita and total $\mathrm{CO}_{2}$ of GCC in 2009 [17].

\begin{tabular}{ccc}
\hline Country & Per capita $\mathrm{CO}_{2}$ emissions, $2009\left(10^{3} \mathrm{~kg} /\right.$ person $)$ & Total $\mathrm{CO}_{2}$ emissions, $2009\left(10^{3} \mathrm{~kg}\right)$ \\
\hline KSA & 78 & 438 \\
Kuwait & 31 & 84 \\
Bahrain & 43 & 31 \\
Oman & 17 & 49 \\
Qatar & 78 & 64 \\
UAE & 41 & 194
\end{tabular}

be higher in GCC countries than the rest of the world [2]. It is reported that in addition to environmental stress which is already increased by economic development, the current GCC countries development policies are detrimental to economic sustainability and should be revised or well-adjusted with novel policies to counter unplanned environmental harms of development [18].

GCC countries are confronted to multi-climate change challenges such as desertification, loss of biodiversity, water scarcity, and sea level rise. The region is also faced with high humidity, high temperature and salt water intrusion into aquifers [19]. Urban planning and clean energy consumption can avoid emission of pollutants while ensuring sustainable development in GCC countries [20].

\section{Renewable Energy in GCC}

Increased energy consumption in the GCC region is, to a certain extent, an inevitable outcome of socio-economic development. However, in the prevailing situation of fluctuation in oil price, rapid population growth and increasing demand of electricity consumption, GCC governments are fully aware that they cannot depend on oil for their revenue forever. As a result, the usage and development of renewable energy resources could make a significant contribution towards improving environmental protection as well as ensuring continuity of oil supplies in secure and stable conditions within the regions [21]. Among the renewable energies, solar and wind are the fastest growing sec- 
tors, primarily due to indigenous abundance and relatively advanced technological development [22]. Solar energy is the most promising source of energy since conditions for solar energy potential for GCC are the most favorable in the world: GCC countries are in a rainless region in the world with $80 \%$ clear skies throughout the years extending from North Africa to Southern Asia [13]. GCC has a substantial solar radiation with Kingdom of Saudi Arabia (KSA) having the highest resource potential.

To deploy renewable energy technology in a country, it is imperative to evaluate the renewable energy resource potential of that country, these includes solar radiation, wind speed and availability of lands for solar PV, Concentrated Solar Power (CSP) and wind farms for electric power generation. The higher the resource value score, the higher the renewable energy readiness score.

Table 3 shows global average solar radiation for $\mathrm{PV}$ is $2083 \mathrm{kWh} / \mathrm{m}^{2} /$ year and that of direct solar radiation for CSP is about $2208 \mathrm{kWh} / \mathrm{m}^{2} /$ year but wind energy potential is moderate with an average speed of $6 \mathrm{~m} / \mathrm{s}$ which varies substantially among the countries [6].

The substantial solar and wind with Qatar, Kuwait, Bahrain and Oman receiving renewable energy readiness score of 5.6, 5.5, 5.3 and 5.2, respectively due to their substantial solar and wind resources. UAE and KSA had a lower score of 4.7 and 4.55 respectively due to their inadequate wind resources.

\section{Some Current Renewable Energy Projects in GCC}

Two most viable renewable energy resources projects common to all GCC countries are solar and wind.

\subsection{Bahrain}

Bahrain pays special attention in the issue of renewable energy and cleaner energy. The authorities in the Kingdom are consistently searching for novel and alternative energy source which is suitable for the local environment. In February 2010, Bapco (Bahrain

Table 3. Solar and wind potential in GCC.

\begin{tabular}{ccccccc}
\hline Country & $\begin{array}{c}\text { PV Global Solar } \\
\text { Radiation } \\
\left(\mathrm{kWh} / \mathrm{m}^{2} / \text { year }\right)\end{array}$ & $\begin{array}{c}\text { CSP Global } \\
\text { Solar Radiation } \\
\left(\mathrm{kWh} / \mathrm{m}^{2} / \text { year }\right)\end{array}$ & $\begin{array}{c}\text { Solar Radiation } \\
\left(\mathrm{kWh} / \mathrm{m}^{2} / \text { year }\right) \\
\text { Score }\end{array}$ & $\begin{array}{c}\text { Wind } \\
\text { Speed } \\
(\mathrm{m} / \mathrm{s})\end{array}$ & $\begin{array}{c}\text { Hours } \\
\text { of Full } \\
\text { Load/Year }\end{array}$ & Score \\
\hline Bahrain & 2160 & 2050 & 5.1 & $5.0-6.0$ & 1360 & 5.5 \\
KSA & 2130 & 2500 & 5.6 & $2.5-4.5$ & 1789 & 3.5 \\
Kuwait & 1900 & 2100 & 5.9 & $5.0-5.5$ & 1605 & 5.2 \\
Oman & 2050 & 2200 & 5.4 & $4.0-6.0$ & 1463 & 5.0 \\
Qatar & 2140 & 2200 & 5.2 & $5.0-7.0$ & 1421 & 6.0 \\
UAE & 2120 & 2200 & 5.4 & $3.5-4.5$ & 1176 & 4.0 \\
\hline
\end{tabular}

Source: [6]. 
Petroleum Company) installed First Zero Emission House project of $7 \mathrm{~kW}$ solar, wind and fuel cell. The house is made up of $4 \mathrm{~kW}$ photovoltaic, $1.5 \mathrm{~kW}$ wind turbine and 1.2 $\mathrm{kW}$ fuel cell. Bapco has also formed a team consisting of University of Bahrain, Electricity and Water Consumption Authority, Ministry of Housing, Ministry of Work, Ministry of Municipality and Agriculture and National Oil and Gas Authority (NOGA) in ensuring follow up and promotion of renewable energy projects in the Kingdom and the world at large [12].

In 2007, two $225 \mathrm{~kW}$ wind turbines were installed at Bahrain World Trading Centre generating approximately $11 \%-15 \%$ of building's electricity requirements. A $5 \mathrm{MW}$ solar PV was launched in 2012, a joint project between Bapco, National Oil and Gas Authority (NOGA) and two other United States based firms; Caspian Energy Holdings and Petra Solar. University of Bahrain Engineering Faculty has produced two mobile solar plant, one for water desalination and a $1.4 \mathrm{~kW} / 100 \mathrm{~W}$ hybrid wind/solar power generation system [9]. There is solar panel factory in Bahrain in collaboration with a Dutch company at a cost of US\$ 200 million [12].

\subsection{Saudi Arabia}

In 2010, King Abdullah's realization of $10 \mathrm{MW}$ initiatives for desalination plant using solar generated energy led to two solar plants in both Al-Khafji and Al-Oyainah. In 2011, Saudi Electricity Company as part of pilot project, commissioned $500 \mathrm{~kW}$ solar plants in Farasan Islands and these plant is capable of being expanded to $6-8 \mathrm{MW}$.

A solar thermal plant with an area of $36,300 \mathrm{~m}^{2}$ was commissioned in 2012, including an addition of Aramco King Abdullah Petroleum Studies and Research Centre solar park in Riyadh which was expanded from 3.5 MW to 5.3 MW [9]. A Vision Electro Mechanical Co, a subsidiary of Construction Products Holding Company has established a company with an amount of $\$ 150$ million for the development, manufacturing and operation of solar power plants to generate electricity in the region [12].

A solar village project of an area of approximately $67,180 \mathrm{~m}^{2}$ utilizes a computerized 350 concentrator solar PV electricity-generating power station that includes $160 \mathrm{PV}$ arrays covering an area of $4000 \mathrm{~m}^{2}$. The project produces an output of $350 \mathrm{~kW}$ direct current (DC). The station distributes 1 to $1.5 \mathrm{MWh} / \mathrm{d}$ of electric energy to three rural villages namely: Al-Jubailah., Al-Uyaynah and Al-Higera [2].

\subsection{Kuwait}

A total of $280 \mathrm{MW}$ solar power plants amounting to US\$ 720 million were installed in Al-Abdaliya and Al-Jahraa. The project was sponsored by partnerships of Technical Bureau through Government of Kuwait and Toyota Tsusho Corporation, Japan [22].

There are number of Research and Development (R\&D) renewable energy projects including two projects on solar cooling, PV systems in street lightning and traffic sign and $151 \mathrm{~kW}$ installed solar power capacity [9]. There is solar thermal application projects such as Sager Al-Rashood Kindergarten with an area of $300 \mathrm{~m}^{2} 90$ solar collector. Thermal electricity project was carried out in places such as Salwa (Kuwait English 
School) with daily electricity load of $630 \mathrm{PV}$ modules and 110 batteries with total electricity production of $24.2 \mathrm{~kW}$ [12].

\subsection{Oman}

Petroleum Development Oman (PDO) launched $7 \mathrm{MW}$ solar thermal plant project to be constructed by Glass Point Company with the aim of producing 11tons/h of high pressure steam used to extract 33 thousand barrels of oil as well as provision of 24hour heating [9]. Ministry of Regional Municipalities and Water Resources installed wind powered electric water-pumping system in remote part of Oman [21]. There is $200 \mathrm{MW}$ concentrated solar power (CSP) project located in Al-Dakhiliya which cost US\$ 600 million [22].

A $25 \mathrm{MW}$ wind energy project is located in Marmul in the southern part of Oman [23]. SQU Ecohouse-project funded by the The Research Council (TRC), the roof top of the building was installed with $156 \mathrm{~m}^{2}$ of $20 \mathrm{~kW}$ peak PV panels [7]. In Sohar, the roof top of Majan Electricity Company (MJEC) was installed with $50 \mathrm{~kW}$ solar PV system covering an area of $325 \mathrm{~m}^{2}$ [24].

\subsection{Qatar}

Inauguration of Qatar Solar Energy (QSE) in 2014 was one of the vertically integrated PV module production facilities in the Middle East and North Africa (MENA). The 300 MW facility is located in Doha [9]. In 2008, Qatar together with United Kingdom established a joint clean energy investment fund of US\$ 400 million to attract foreign investment projects relation to clean energy technology development [4]. Energy efficient house was constructed in Baytna villa, a project which was undertaken by Qatar Green Energy Council was constructed with PV array with a peak power of $34 \mathrm{~kW}$ [7]. Also, under the auspices of Qatar Foundation, Qatar Environment and Energy Research Institute was inaugurated in 2011 to carryout research in the area of solar photovoltaics, energy storage technologies and grid integration in collaboration with Qatar Solar Technologies, Pacific Northwest National Laboratory, Oak Ridge National Laboratory and University of California, Los Angeles [4]. Solar Test Facility at Qatar Science and Technology Park is 35,200 $\mathrm{m}^{2}$ open field, grid-connected test site located at Education City, $10 \mathrm{~km}$ from Doha, the aim of this facility is to contribute in achieving Qatar's sustainable energy targets [25].

\subsection{UAE}

Solar PV is growing at a faster rate and the United Arab Emirates leads the Gulf Region in PV electricity generation. UAE launched a $100 \mathrm{MW}$ concentrated solar power (CSP) Sham-1 at Madinat Zayed at Abu Dhabi in March 2013 extending over an area of 2.5 $\mathrm{km}^{2}$ and its considered as world largest CSP [26]. This will be followed by two other projects Sham-2 and Sham-3 with extra capacity of 150 MW. Masdar city in UAE is equipped with solar PV facility [20].

There are also small scaled solar PV projects including: $1 \mathrm{MW}$ rooftop installation at 
Masdar Institute; Yas Marina circuit is equipped with $291 \mathrm{~kW}$ PV array, Masdar city parking shade has been installed with $204 \mathrm{~kW} \mathrm{PV;} \mathrm{and} 200 \mathrm{~kW}$ mounted an Presidential Sea Palace. Al Qarneed Island and Marawah Island have solar PV of $0.75 \mathrm{MW}$ and 0.49 MW respectively [9]. Waste-energy project in Sharjah which is completing tendering will produce $53 \mathrm{MW}$ of power [27]. A large $850 \mathrm{~kW}$ wind turbin has been constructed at Sir Bani Yas Island located at $250 \mathrm{~km}$ southwest Abu Dhabi [26]. International research collaboration was signed between Masdar Institute and Massachusettes Institute of Technology (MIT) for the development of renewable energy technologies. Among some of the research foci includes: transformations such as advanced solar energy technologies, offshore and onshore wind energy, biofuels, geothermal, wave and tidal energy; global systems including science and policy of global change, building and urban systems and vehicles and transportation system and innovations which comprises carbon capture and sequestration, power electronics, heat management [4]. The iconic tower-Burj Khalifa was installed in April 2010 with 378 solar collector panels of $2.7 \mathrm{~m}^{2}$ area each to heat about $140,000 \mathrm{~L}$ of water per day for in-house consumption with energy savings equivalent to $3200 \mathrm{~kW}$ per day. Turbine being the third largest in solar desalination after US and Saudi Arabia is taking initiatives to use solar energy for such purpose. The Environment Agency-Abu Dhabi (EAD) constructed 22 small scale solar desalination plants which are capable of producing 11,000 cubic meters of water a year [22].

\section{Future Renewable Energy Projects in the GCC}

The main investors of renewable energy in Middle East are GCC countries, it is expected that by the year 2020, the new solar and wind energy would have reached 10 GW. World Energy Council (WEC) estimated that the total current $\mathrm{CO}_{2}$ emission to the planet caused by the GCC countries are not more than $2.25 \%(0.1 \%$ for Bahrain, 0.4\% for UAE, $0.1 \%$ for Oman, $0.2 \%$ Qatar, $1.2 \%$ Saudi Arabia and $0.2 \%$ for Kuwait). GCC countries will require extra $100 \mathrm{GW}$ of power for the next ten years to meet its growing energy demand [12].

However, planning energy processes requires critical study of demand and supply, prediction of trends of input-output items based on economic, technological models and strategies to diversify the sources of energy [9]. International Renewable Energy Agency (IRENA) based in Abu Dhabi estimates that the six GCC countries returns through renewable energy integration could reach US\$ 200 billion [22]. This review tried to summarize in Table 4, the GCC state's national future projections on renewable energy projects in the coming years.

\section{Co-Benefits of RE to GCC Countries}

Apart from reducing the future impact of climate change by GCC countries through investment in renewable energy technologies and projects, GCC states will also benefits from reduction in highly subsidized domestic fuel consumption and exportation abilities. They will be well prepared during post-oil age, thus their energy infrastructure 
Table 4. Future renewable energy for GCC countries.

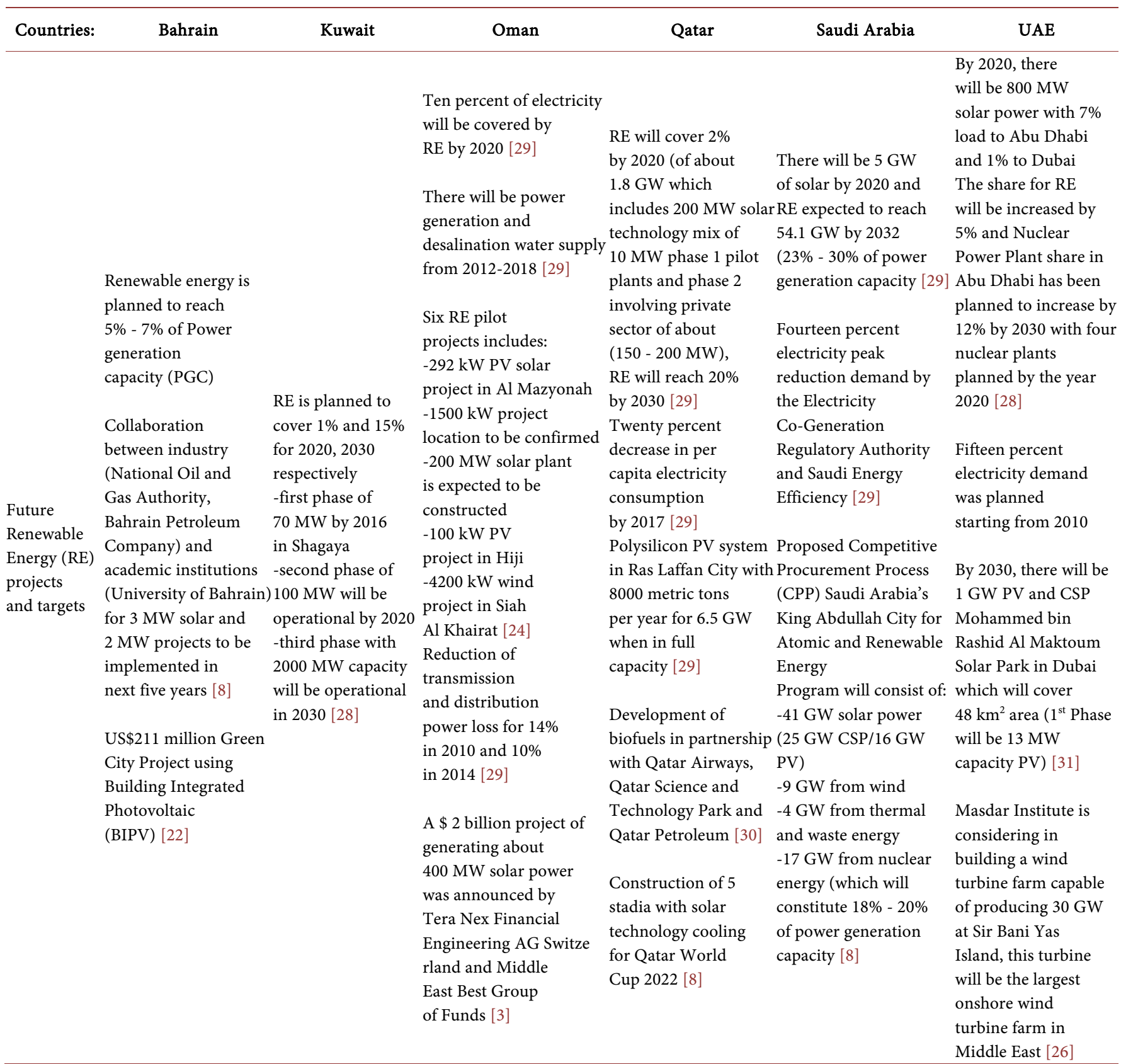

would be ready for a period where domestic oil and natural gas get limited. Also more sustainable policies in renewable energy will give GCC countries a better reputation in international policy arena [1]. The use of solar energy will especially leads to the following benefits: reclamation of land; reduction on emphasis on national power grid network; ameliorate water quality problems across the countries since there will be reduction in groundwater pollution from oil extraction and also accelerated electrification projects in rural remote areas [28].

Some of the manifold benefits that GCC countries can derive from developing re- 
newable energy projects are:

- Diversifying the economy to lessen the burden on aging power infrastructure.

- Provision of parallel energy support network to population boom and rapid urbanization.

- Promote capacity development for a knowledge-based economy.

- Better management of the demand-supply gap by compensating for indigenous shortage of oil or gas or both [22].

\section{Policy Approaches and Strategies}

GCC member states has established administrative capacities tackling climate change issues: the Ministry of Environment and Climate Affairs in Oman, the Public Commission for the Protection of Marine Resources, Environment and Wildlife in Bahrain, the Environment and Public Authority in Kuwait, the Supreme Council for the Environment and Natural Reserves in Qatar, the Presidency of Meteorology and Environment in Saudi Arabia, and the Federal Environment Agency as well as the Ministry of Environment and Water Resources in United Arab Emirates [13]. These institutions, however, often have some limited capacities and minimal influence when it comes to domestic policy processes. No GCC country has a consistent policy framework regarding renewable energies and energy efficiency but there are remarkable ongoing projects in the GCC countries which are also known to the global community. As shown in Table 4, GCC states also have national future projections on renewable energy projects in coming years.

Developing a self-sustainable domestic market for renewable energies needs concerted efforts which aid in further development, application, and diffusion of those resources [29]. Focusing on policy formulations framework that encourage transition to renewable energy development pathway, the development and changes in policies as well setting up institutions may help in surmounting the current structural weakness which will spur a wide spectrum in renewable energy source deployment [30]. Power Purchasing Agreements (PPA) whereby partnership between Governments and developers on renewable energy is fruitful and provides equal opportunities to renewable energy source power to compete with the heavily subsidized conventional energy sources [29]. Adoption of renewable energy technologies from the pioneering countries can be infused through policy transfer [4]. Policy transfer can be seen as a set of "processes where a nation learn from or imitates policies implemented elsewhere through bilateral communication and direct interaction or exchange of experiences" [31]. This allows policy makers to search for alternative policy solutions that are successful in other countries. Hence, policy transfer concept can be used as a channel through which renewable energy policy and technological knowledge can be disseminated.

\section{Conclusion}

Renewable energy investments are increasingly growing in the GCC, primarily due to 
the awakening in the region to stem the faster depletion of finite oil and gas reserves. This move in fact creates a platform to prepare themselves towards their commitment to UNFCCC in greenhouse gas reduction towards sustainable development. While some countries such as UAE and Saudi Arabia are leading the renewable energy projects, other members can leapfrog by employing policy transfer mechanisms, interregional collaboration and business partnerships. However many critics say, it will be a challenge to implement these renewable energy projects and technologies without clear cut policies and regulatory framework. Hence, GCC has to use stable and sustainable policies towards renewable energy deployment goals. These sustainable policies in renewable energy will also give them a better image in arena of international environmental and climate change policy. Research and development is important in realizing these goals since it creates knowledge-based economy and invests in human capital stock for the future generation. In addition the co-benefits of investing in renewable energy will immensely benefit the economy in the long-term future. Though any amount of efforts will take its own time, without a doubt the slow transition from being a hydrocarbon economy to low carbon economy is necessary and bound to happen at one point of time at least in the far future.

\section{References}

[1] Reiche, D. (2010) Renewable Energy Policies in the Gulf Countries: A Case Study of the Carbon-Neutral 'Masdar City' in Abu Dhabi. Energy Policy, 38, 378-382. http://dx.doi.org/10.1016/j.enpol.2009.09.028

[2] Bhutto, A.W., Bazmi, A.A., Zahedi, G. and Klemeš, J.J. (2014) A Review of Progress in Renewable Energy Implementation in the Gulf Cooperation Council Countries. Journal of Cleaner Production, 71, 168-180. http://dx.doi.org/10.1016/j.jclepro.2013.12.073

[3] IEA (2013) Non-Member Countries. http://www.iea.org/countries/non-membercountries/

[4] Atalay, Y., Biermann, F. and Kalfagianni, A. (2016) Adoption of Renewable Energy Technologies in Oil-Rich Countries: Explaining Policy Variation in the Gulf Cooperation Council States. Renewable Energy, 85, 206-214. http://dx.doi.org/10.1016/j.renene.2015.06.045

[5] Salahuddin, M. and Gow, J. (2014) Economic Growth, Energy Consumption and $\mathrm{CO}_{2}$ Emissions in Gulf Cooperation Council Countries. Energy, 73, 44-58. http://dx.doi.org/10.1016/j.energy.2014.05.054

[6] Mondal, M.A.H., Hawila, D., Kennedy, S. and Mezher, T. (2016) The GCC Countries REReadiness: Strengths and Gaps for Development of Renewable Energy Technologies. Renewable \& Sustainable Energy Reviews, 54, 1114-1128. http://dx.doi.org/10.1016/j.rser.2015.10.098

[7] Alalouch, C., Saleh, M.S. and Al-Saadi, S. (2016) Energy-Efficient House in the GCC Region. Procedia-Social and Behavioral Sciences, 216, 736-743. http://dx.doi.org/10.1016/j.sbspro.2015.12.071

[8] Asif, M. (2016) Growth and Sustainability Trends in the Buildings Sector in the GCC Region with Particular Reference to the KSA and UAE. Renewable \& Sustainable Energy Reviews, 55, 1267-1273. http://dx.doi.org/10.1016/j.rser.2015.05.042

[9] Abdmouleh, Z., Alammari, R.A.M. and Gastli, A. (2015) Recommendations on Renewable Energy Policies for the GCC Countries. Renewable \& Sustainable Energy Reviews, 50, 11811191. http://dx.doi.org/10.1016/j.rser.2015.05.057 
[10] Sardorsky, P. (2011) Trade and Energy Consumption in the Middle East Energy. Journal of Economics, 33, 739-749.

[11] Hertog, S. and Luciani, G. (2009) Energy and Sustainable Policies in the GCC. London School of Economics, London.

[12] Alnaser, W.E. and Alnaser, N.W. (2011) The Status of Renewable Energy in the GCC Countries. Renewable \& Sustainable Energy Reviews, 15, 3074-3098. http://dx.doi.org/10.1016/j.rser.2011.03.021

[13] Reiche, D. (2010) Energy Policies of Gulf Cooperation Council (GCC) Countries-Possibilities and Limitations of Ecological Modernization in Rentier States. Energy Policy, 38, 2395-2403. http://dx.doi.org/10.1016/j.enpol.2009.12.031

[14] UNDP (2007) Human Development Report 2007-2008. UNDP, New York.

[15] IEA (2012) International Energy Agency.

[16] World Bank (2016) Electric Power Consumption (kWh per Capita) | Data | Graph. http://data.worldbank.org/indicator/EG.USE.ELEC.KH.PC/countries/BH-SA-QA-OM-AE$\underline{K W}$ ?display=graph

[17] Agrawala, S., Moehena, A., El Raey, M., Conway, D., van Alist, M., Hagenstad, M. and Smith, J. (2004) Development and Climate Change in Egypt: Focus on Coastal Resources and the Nile. Oranisation for Economic Co-Operation and Development.

[18] Sweidan, O.D. and Alwaked, A.A. (2016) Economic Development and the Energy Intensity of Human Well-Being: Evidence from the GCC Countries. Renewable \& Sustainable Energy Reviews, 55, 1363-1369. http://dx.doi.org/10.1016/j.rser.2015.06.001

[19] Al-Olaimy, T. (2015) Climate Change Impact on GCC. EcoMENA-Echoing Sustainability.

[20] Asif, M., Sharma, R.B. and Adow, A.H.E. (2015) An Empirical Investigation of the Relationship between Economic Growth, Urbanization, Energy Consumption, and $\mathrm{CO}_{2}$ Emission in GCC Countries: A Panel Data Analysis. Asian Social Science, 11, 270-284.

http://dx.doi.org/10.5539/ass.v11n21p270

[21] Doukas, H., Patlitzianas, K.D., Kagiannas, A.G. and Psarras, J. (2006) Renewable Energy Sources and Rationale Use of Energy Development in the Countries of GCC: Myth or Reality? Renewable Energy, 31, 755-770. http://dx.doi.org/10.1016/j.renene.2005.05.010

[22] Munawwar, S. and Ghedira, H. (2014) A Review of Renewable Energy and Solar Industry Growth in the GCC Region. Energy Procedia, 57, 3191-3202.

http://dx.doi.org/10.1016/j.egypro.2015.06.069

[23] Solanki, P.S., Mallela, V.S. and Zhou, C.K. (2013) Estimation and Diminution of $\mathrm{CO}_{2}$ Emissions by Clean Development Mechanism Option at Power Sector in Oman. International Journal of Energy and Environment, 4, 641-652. http://ijee.ieefoundation.org/vol4/issue4/IJEE 08 v4n4.pdf

[24] Albadi, M., Al Abri, R., Masoud, M., Al Saidi, K., Al Busaidi, A., Al Lawati, A., Al Ajmi, K. and Al Farsi, I. (2014) Design of a $50 \mathrm{~kW}$ Solar PV Rooftop System. International Journal of Smart Grid and Clean Energy, 3, 401-409.

[25] Diego, M.-P., Abdallah, A., Figgis, B.W. and Mirza, T. (2015) Performance Improvement Techniques for Photovoltaic Systems in Qatar: Results of first Year Eutdoor Exposure. Energy Procedia, 77, 386-396. http://dx.doi.org/10.1016/j.egypro.2015.07.054

[26] Jamil, M., Ahmad, F. and Jeon, Y.J. (2016) Renewable Energy Technologies Adopted by the UAE: Prospects and Challenges-A Comprehensive Overview. Renewable \& Sustainable Energy Reviews, 55, 1181-1194. http://dx.doi.org/10.1016/j.rser.2015.05.087

[27] Sgouridis, S., Abdullah, A., Griffiths, S., Saygin, D., Wagner, N., Gielen, D., Reinisch, H. 
and McQueen, D. (2016) RE-Mapping the UAE's Energy Transition: An Economy-Wide Assessment of Renewable Energy Options and Their Policy Implications. Renewable \& Sustainable Energy Reviews, 55, 1166-1180. http://dx.doi.org/10.1016/j.rser.2015.05.039

[28] Nematollahi, O., Hoghooghi, H., Rasti, M. and Sedaghat, A. (2016) Energy Demands and Renewable Energy Resources in the Middle East. Renewable \& Sustainable Energy Reviews, 54, 1172-1181. http://dx.doi.org/10.1016/j.rser.2015.10.058

[29] Khondaker, A.N., Hasan, M.A., Rahman, S.M., Malik, K., Shafiullah, M. and Muhyedeen, M.A. (2016) Greenhouse Gas Emissions from Energy Sector in the United Arab Emirates-An Overview. Renewable \& Sustainable Energy Reviews, 59, 1317-1325.

http://dx.doi.org/10.1016/j.rser.2016.01.027

[30] Ferroukhi, R., Ghazal-Aswad, N., Androulaki, S., Hawila, D. and Mezher, T.T. (2013) Renewable Energy in the GCC: Status and Challenges. International Journal of Energy Sector Management, 7, 84-112. http://dx.doi.org/10.1108/17506221311316498

[31] Busch, P. and Jorgen, H. (2005) International Pattern of Environmental Policy Change and Convergence. European Environment, 15, 80-101. http://dx.doi.org/10.1002/eet.374

Submit or recommend next manuscript to SCIRP and we will provide best service for you:

Accepting pre-submission inquiries through Email, Facebook, LinkedIn, Twitter, etc. A wide selection of journals (inclusive of 9 subjects, more than 200 journals)

Providing 24-hour high-quality service

User-friendly online submission system

Fair and swift peer-review system

Efficient typesetting and proofreading procedure

Display of the result of downloads and visits, as well as the number of cited articles Maximum dissemination of your research work

Submit your manuscript at: http://papersubmission.scirp.org/ 